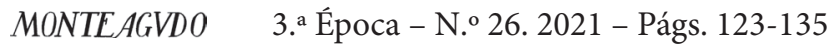

\title{
Un BREVE RECORRIDO POR LA POESÍA DE RAMÓN GAYA
}

\author{
Laura Mariateresa Durante \\ Universidad de Nápoles Federico II
}

\section{RESUMEN:}

Además de la pintura y de la escritura ensayística, Ramón Gaya se dedicó a la poesía y, aunque sea una faceta poco conocida, lo hizo muy tempranamente. Esta contribución pretende ofrecer una visión panorámica de la producción poética del autor, desde las primeras obras en poesía hasta los poemas de la madurez. Asimismo, se propone añadir algunas reflexiones sobre este aspecto inédito del pintor de Murcia.

\section{PALABRAS CLAVE:}

Poesía, pintura, arte, Italia, vanguardia.

\begin{abstract}
:
Oltre alla pittura e alla scrittura saggistica Ramón Gaya si è dedicato alla poesia e, nonostante, non sia noto, questa attività giunse anticipatamente. Il contributo desidera offrire una panoramica sulla produzione poetica dell'autore dalle prime opere in poesia fino ai poemi della maurità. Si propone, inoltre, di aggiungere alcune riflessioni su questo aspetto inedito del pittore di Murcia.
\end{abstract}

\section{PAROLE CHIAVE:}

Poesia, pittura, arte, Italia, avanguardia.

Además de ser gran pintor y ensayista de notable perspicacia, Ramón Gaya se dedicó a la poesía ${ }^{1}$. Sin embargo esta, aunque no sea vacacional, como ha subrayado Pérez Sánchez ${ }^{2}$, se delinea como una actividad que sigue a la pintura que, como se sabe, coincide casi con la misma vida del autor. Le sigue la escritura de ensayos, que, según Gaya, representan una manera de aclararse, de dilucidar sus reflexiones sobre el arte. Escribe él mismo:

Yo apenas escribo poesía. En 1931 compuse un librito de versos, pero hace poco lo he hecho desaparecer. Suelo escribir poemas cuando lo he sentido o lo quiero expresar, o

\footnotetext{
${ }^{1}$ Agradecemos a Isabel Verdejo por la ayuda amistosa.

${ }^{2}$ «No creo que sus poemas debamos entenderlos como fruto ocasional, como una dedicación vacacional y dominguera. Gaya no es un pintor que en ocasiones haga versos, sino un pintor hondamente poeta, cuya "sustancia" se decanta por igual sobre el lienzo y las cuartillas» (Pérez, 2002: 35-46).
} 
atrapar, o señalar, de ninguna manera puedo pintarlo. Muchos de esos poemas son casi pensamiento estético, obedecen a una reflexión sobre el arte. Pero siempre se cuela en ellos, por algunos resquicios, un aliento poético, como el que aparece en mi pintura. También ha sido esto lo que me ha impedido escribir más poesía. El poeta que yo hubiera podido ser se cumplía de una forma terminante y esencial en la pintura. Con el título de Algunos poemas del pintor Ramón Gaya he seleccionado para la editorial La Veleta, de Granada, lo que considero más válido (2008: 239).

De hecho, dejando el volumen de poemas citado (1991) y la publicación Algunos poemas (2001), la producción poética de Gaya está presente a lo largo de su vida ${ }^{3}$ a raíz de que su vena poética encontrase su cauce natural en la pintura. El autor eligió la materia de la palabra y del ritmo solamente cuando la pintura no le permitía expresarse con toda naturalidad. En una conocida entrevista a Elena Aub el autor, sobre este punto, declaró:

Cuando escribo no puedo pintar, y cuando pinto no puedo escribir, en absoluto. No porque salgan de dos lugares distintos, salen del mismo - esto me lo he preguntado-. Yo creo que salen del mismo lugar las dos cosas; lo que pasa es que, como son dos materias distintas, necesito un tiempo distinto, un espacio distinto; hasta el ritmo es diferente. [...] Cuando escribo -tanto en la poesía como en el ensayo, que es lo que escribo, yo no escribo novela- tengo un ritmo más lento. En mí, escribir es igualmente importante y legítimo, como pintar, pero no tengo esas facultades. Es decir, tengo que construir más, lo tengo que hacer, tengo que ir a por ello. Cosa que no me pasa en la pintura, la pintura me la encuentro más hecha como oficio. (2008: 170-171).

Para Gaya, la poesía viene a ser una actividad creadora con un tiempo más lento, que emerge cuando la absorbente actividad pictórica no lo ocupa. Por lo que se desprende de la cita arriba mencionada, nos parece evidente que la poesía entra en la vida de Gaya en los momentos en que la pintura no consigue llegar a expresar. Además, es importante revelar que el mismo Gaya, a pesar de considerarse poeta, en el sentido de que cualquier creador de arte es poeta, puso su producción lírica en segundo plano. Para aclararlo, Gaya declaró:

\footnotetext{
3 «Los hospicianos», El mono azul, I, 9 (22 de octubre de 1936); «Diario de un pintor: Pequeños poemas a mi país, mi mujer y mi hija», Hora de España, 15 (marzo de 1938), págs. 87-89; «Diario de un pintor. Pequeños poemas: Los mutilados; Hermosura de la guerra», Hora de España, 18 (junio de 1938), pág. 41; «Sonetos de un diario: A una verdad; Al silencio; Al sufrimiento; A Dios; A la lámpara; A mis amigos», Taller, 7 (diciembre de 1939), págs. 23-26; «Poemas de un diario. Tiempo; Tarde [I]; Tarde [II]; Tarde [III]; Al destino», De mar a mar (Buenos Aires), II, 6 (mayo de 1943), págs.. 14-18; «Diario de un pintor: Un ademán, el aire; Asistimos estamos; Aquí está con nosotros», El Hijo Pródigo, IV, 41 (15 de agosto de 1946), págs. 79-81; «Diario de un pintor. Vuelto hacia sí; La casa de Dios; Epitalamio; Tarde», Creación y crítica (México), I (1948); «Del pintar: Sonetos II, III, IV», Catálogo de exposición, Chys: Galería de Arte, Valencia, 1977, págs. 5-9.
} 
Todo arte es poesía. [...] La poesía no es una de las artes. La poesía está en todas. La poesía está en todas las artes. La poesía es algo que está en el hombre, un sentimiento que está en todos. [...] Quizá, aunque yo creo que soy poeta y que tengo caudal poético. Lo que pasa es que creo que ese caudal poético que poseo lo expreso mejor en la pintura que en la poesía. Allí está el asunto. No es que no sepa escribir un soneto, he escrito algunos e incluso un reducido número de personas me los ha aplaudido; pero yo niego los oficios de la creación. Bueno, los niego por una parte, aunque por otra sé que existen. Quiero decir que lo que me parece importantísimo no es tanto el hacer el verso (eso lo sabe hacer cualquiera), como tener verso. Porque yo hago una diferencia entre hacer cosas y serlas, ¿verdad? Todo lo que es creación es ser esas cosas, no hacerlas. La creación no hace. Por eso digo que el creador espera, porque tiene que esperar eso que ya es el creador. (2008: 230-231).

Para desentrañar este argumento, Gaya explica: «Así es que, como decíamos, he escrito pocos poemas porque lo que sucede es que siento que no tengo verso propio. El verso no está en mí. [...] Yo puedo hacer un endecasílabo, como lo puede hacer cualquiera, pero siempre sería, como si dijéramos, un endecasílabo hecho» (2008: 230-231). Al parecer del autor, tener el verso «hecho» es no tener que trabajarlo, es un don reservado a pocos. Resulta, entonces, evidente cómo en la creación poética hay un verso construido, hecho, como subraya el autor, y un verso que aflora con naturalidad y que es propio del poeta natural, en que Gaya no se reconoce.

Fue posiblemente Octavio Paz quien se fijó por primera vez en cómo, en la pintura de Gaya, no queda huella de las vicisitudes de la vida, ni de los sentimientos: «Si su pintura no está contaminada por las ideas, ¿lo estará, acaso, por los sentimientos? -se pregunta Paz- En aparencia nada menos sentimental, menos emotivo, que la pintura de Gaya. [...] Ni sentimientos ni sensaciones invaden la atmósfera cerrada de sus cuadros; su corazón no hace temblar su pulso tranquilo y exacto» (Paz, 1996). Creemos que precisamente este lado emotivo, borrado en la pintura, si no aparece en toda la producción poética gayesca, sí se evidencia visiblemente en una parte de esta. No hacemos referencia a los versos más comprometidos con la causa republicana ni a los que Gaya dedica a la creación pictórica. Hablamos, en cambio, de aquella en que Gaya manifiesta sus pensamientos más íntimos: los recuerdos de la primera mujer fallecida, la hija lejana, la soledad y el destierro. Es necesario evidenciar que las palabras de Gaya nunca gritan su dolor, pero lo dejan aflorar ligeramente en la superficie. Son sentimentos que aparecen en algunos poemas estrechamente conectados con las experiencias del período mexicano.

Respecto a las publicaciones poéticas, estas rondan las treinta y cinco. Las creaciones poéticas están presentes en su vida desde la primera juventud hasta la madurez y difieren tanto en versificación como en temática. Para tratar de analizar 
la actividad poética de Gaya, hemos dividido su producción en ejes temáticos: 1) los versos de la juventud; 2) los poemas de la guerra civil; 3) las líricas del exilio mexicano; y 4) los poemas en que el tema de la pintura se desarolla en poesía. Entre esos últimos incluimos el soneto «El Tevere a su paso por Roma»y similares, dedicados a retratar un paisaje o un estado de ánimo con palabras. Analizaremos los últimos tres apartados ya que, como se mencionó más arriba, los versos de junventud fueron rechazados por el mismo autor. Es Ramón Gaya, en una entrevista, quien declaró lo siguiente: «A los quince años escribo unos poemas en prosa [...]. Hay unos poemas en prosa publicados en Verso y Prosa, la revista que fundaron Juan Guerrero y Jorge Guillén [...]. Bueno, esos poemas míos no es que sean cursis, pecan de otra cosa; son unos poemas en prosa y están escritos con una forma demasiado imitativa de la forma de Ramón Gómez de la Serna» (2008: 108-109). El autor subraya también que su amigo José Bergamín, al releer los versos publicados en una reedición de la revista Verso y Prosa, comentó de acuerdo con el autor que

la forma era escandalosamente ramoniana, pero no el contenido. Es decir, el material era mío, pero debido a mi juventud necesité apoyarme en un autor con experiencia y al que admiraba. Creo que todo creador joven, cuando empieza, percibe cosas, emociones en la realidad que quiere expresar, trasmitir, pero si es muy joven carece de forma de expresión, está desnudo, entonces se echa encima la capa de otro, llámese Ramón Gómez de la Serna o Dante; eso es legítimo, después con la experiencia ya se irá despojando de esas influencias. La percepción de las emociones se tiene muy pronto, pero se carece de verbo: en arte lo último es el verbo. En la tradición judeocristiana lo primero es el verbo, pero en la creación artística no, la trayectoria de un artista no es más que encontrar ese verbo. (2008: 110).

La cita es necesaria para perfilar el pensamiento del pintor no solo en materia de escritura sino en materia de pintura, y no es casual que Gaya siga citando el caso de Cézanne. Al comienzo de su itinerario poético, le falta a Ramón Gaya lo que él define como verbo, pero no tardará en adquirirlo. Sin embargo, tendrá que llegar la dramática experiencia del exilio.

En octubre de 1936 se publica una de las primeras composiciones poéticas, después de las de Verso y Prosa ${ }^{4}$, «Los hospicianos» (El mono azul, I, 9, 22 de octubre de 1936). Se trata de una lírica escrita para El Mono azul y, sin quitar mérito a Gaya, no se puede olvidar que estos son unos versos comprometidos con el bando

\footnotetext{
${ }^{4}$ Hora de España n. ${ }^{\circ}$ 15, marzo 1938, pp. 87-89. En realidad, anterior a «Los Hospicianos» es la composición «La calma del esposo», fechada en «España, 1934» e incluida en su obra completa (2010), pero no dudamos de que forman parte de los versos de juventud de Ramón Gaya. Preferimos dejarla de lado aquí para analizar la producción de la guerra civil, que queda como documento histórico de aquel tiempo y de la vida de nuestro autor.
} 
republicano. En comparación con los poemas de madurez, este poema carece de autenticidad. Algo similar, como ya afirmamos (Durante, 2013: 64-66), se puede detectar en un artículo de 1937, «Carta a un Juan», que nos recuerda al tono de un ensayo de María Zambrano (Durante, 2008: 223-245). En «Los hospicianos», tal vez a raíz del verso poético, este tono aparece más fuerte. Es evidentemente un poema de propaganda, cuyo tema hace referencia a lo que se contaba sobre los nacionalistas, que habían llamado a combatir al frente a unos niños sacados del Hospicio para huérfanos de Sevilla. Alrededor de este tema tan dramático se entrelazan los versos sobre las antítesis vida-muerte, fascistas-niños, hospicio-frente, temblor-calor, hombre anónimo que trabaja-canalla destructor. El tono emotivo y verídico no falta en esta composición; sin embargo, es difícil reconocer en ella la escritura del Gaya que conocemos. La acritud se pone de manifiesto en los versos «iCatólicos de escayola, / qué falsas son vuestras misas!»o «iQué sangre más insensible /es la sangre señorita! / ¡No hay más sangre que la roja, la que es azul es podrida!», palabras estas que suenan extremadamente insólitas en Gaya, que en el porvenir se mantendrá lejos de lo político. En cambio, los versos que forman parte de «Diario de un pintor», pese a que fueron escritos en el mismo período, resultan más autenticos e íntimos. Son «Pequeños poemas. A mi País, mi mujer y mi hija», que aparecieron en Hora de España ${ }^{5}$ en marzo de 1938. Las tres composiciones en cuartetas, como rezan los títulos, están dedicadas a todo lo que Ramón Gaya quiere y que muy pronto perderá: la patria y su mujer, en 1939; y su hija, Alicia, a la que tuvo que dejar en Europa al cuidado de la familia Hall. Se percibe una fuerza emotiva en palabras como «rincón de desdicha» o en el primer verso dedicado a su mujer «No vendrás, estoy lejos», en que el autor comunica la tristeza de no volver a verla. Mientras, «Qué sencillo es quererte», verso con el que comienza el poema dedicado a Alicia, tiene la pureza del cariño de Gaya hacia la niña. Se trata, pues, de versos que, a pesar de que los compone en un momento dramático, trasmiten la verdadera preocupación de nuestro autor, que no reflexiona sobre la guerra o sobre el enemigo, como sucedía en «Los Hospicianos», y comunica las dificultades de la vida diaria durante el período

\footnotetext{
${ }^{5}$ Sobre el tema de la revista Hora de España, véase Muñoz (2011) y las interesantes observaciones que apunta. En estas, el filósofo en tema de propaganda escribe: «que jamás fue una revista "de propaganda" ni subordinó la lógica de la creación intelectual a los mandatos del comisario político de turno, o a exigencias ajenas a las de la veracidad y la calidad». Muñoz apoya sus afirmaciones, además de sobre los textos de Hora de España, sobre el entrañable discurso de 1937 que fue pronunciado en el II Congreso de escritores organizado por la Alianza Internacional de Intelectales Antifascistas y que pone el acento en la independencia de pensamiento. No cabe duda de que muchos siguieron siendo independientes de la propaganda republicana, pero es también cierto que Gaya, como otros, María Zambrano entre ellos, tuvieron una producción tanto en verso como en prosa extremadamente alejada de la que nace en otros períodos históricos, y no solo por el estilo, sino por el contenido que se aleja mucho de los temas tratados antes y después el conflicto civil.
} 
bélico. Se acercan a este estilo de escritura otros dos poemas: «Hermosura en la guerra» y "Los mutilados», ambos publicados en 1938 en Hora de España. Los dos en cuartetas se aproximan al tema de la naturaleza. El primero se centra en la hermosura de la primavera, mientras en el segundo poema Gaya se detiene en el cambio que se produce en los hombres que fueron a la guerra y volvieron diferentes: no son los de antes, tienen un «vacío». Los dos poemas no dejan entrever aquella nota propagandística que hemos visto y que ya no volverá a aparecer en los versos de Gaya.

Los poemas que nacerán después de abandonar España parecen llegar de un lugar abismal, de la soledad absoluta en que el autor reside desde 1939 y en que vivirá durante varias décadas. Es él mismo quien, hablando con Nigel Dennis, admite: «Di, hace años, como sabes, esos nueve sonetos que son de varios años de mi vida. Hay dos que son de 1940, creo. Pertenecen a un grupo de sonetos que escribí en ese momento, y que se referían a una situación mía muy dolorosa, a una pérdida muy dolorosa para mí. Surgieron así esos sonetos» (2008: 232-233). Aunque no quede claro con certeza cuáles son los dos poemas citados, los versos publicados en el exilio mexicano surgen de la angustia en que Gaya vivía. «Seis sonetos de un diario ${ }^{6}$ de 1939 representan la prueba más viva de cómo la desesperación del autor desemboca naturalmente en poesía. Bien lo sabe Manuel Andújar, que citamos.

En los «Sonetos de un diario» (diciembre 1939) dedicados «A una verdad», «Al silencio», «Al sufrimiento», «A Dios», «A la Lámpara», «A mis amigos», los versos llegando con tu luz hasta mi angustia y No es el amor quien muere, /él es quien mata preludian el "estado de alma" -y situación conceptual- que moverán a Gaya, en su prosa incisiva, al reincidiente empleo de dos vocablos-imágenes, de tono adivinatorio y correlativo, que fijan el término de sus procesos y sus colmadas y agudas doctrinas: pasmo, embeleso. (1980: 43-47)

Por lo que concierne a los sonetos de Taller, hay que detenerse también en el análisis de Pascual Gay sobre el reiterarse de unas palabras que podríamos llamar clave en el lenguaje poético de Gaya. De hecho, si términos como «expresión»o «nido» se encuentran a menudo en los versos del autor, los que sustentan los poemas del exilio son otros. «Lo perdido» del cuarto verso del poema «Al Silencio» vuelve en el verso «Me lo has quitado todo» de «Al sufrimiento», así como en el íncipit en que Gaya dice «Me despojas de todo» en «A Dios» $\mathrm{y}$, al final de este soneto, cuando escribe «Me arrancaste mi llanto, y ya no lloro; / me arrancaste mi vida, y ya no vivo; si el morir me arrebatas ¿qué me dejas?». Son palabras de dolor que volvemos a

\footnotetext{
${ }^{6}$ La idea del «Diario» en Ramón Gaya viene desde lejos y llega hasta los años 80, cuando se publica Diario de un pintor (1984).
} 
encontrar en el tercer verso de «A la lámpara» ${ }^{7}$ en que leemos «aquí junto a un pasado sólo huellas» y en el término «vacío», que se repite en el poema que Gaya dedica «A mis amigos». El dolor y la soledad son por consiguiente las emociones que, con toda evidencia, empapan cada palabra de los poemas del primer año del exilio de Ramón Gaya en tierra azteca. Es el poeta Tomás Segovia quien reitera lo que observamos al principio de nuestro itinerario poetico. Sobre Gaya escribe: «Cuando se siente paralizado como pintor porque se niega a entregarse al espectáculo de su dolor, la poesía se abre inmediatamente ante él como un pensamiento interior, un sentimiento que puede sentir con los ojos cerrados, un camino de verdad que no pasa por el espectáculo» (1995: 346). Todo lo que acabamos de leer y sobre lo que insistimos se hace aún más evidente en unos poemas inéditos hasta el 2010, fecha en que se publicó la Obra completa de Gaya, que reúne unas composiciones poéticas, posiblemente demasiado personales para que nuestro autor quisiera publicarlas antes de su muerte. Los poemas son «Nana del olvido»-México, agosto de 1939-, «Pequeña piedra de adhesión» (1939), «Canción extraña» (marzo de 1940) y, finalmente, «Nana para un Lázaro», en que el editor señala cómo, a pesar de no tener anotaciones de Gaya, resulta escrita en el cuaderno de apuntes de los poemas precedentes. La liríca más entrañable es aquella titulada «Nana del olvido», en que el autor, a pesar de no hacer alguna referencia especifica, se dirige a la hija en la lejana Europa: «Tú, allá a lo lejos, / Yo, queriendo ser otro, / yo siendo el mismo; / tú, dormida o despierta, / siendo el olvido. /Tú, sin mis besos». Se trata de una composición que, pese a los pocos versos, trasmite la lejanía de todo lo querido por el autor. Mientras otros exiliados seguían creyendo en una posible vuelta a España, Gaya estaba totalmente desesperanzado. No conseguía ver un posible retorno ni para sí mismo, ni para la pequeña Alicia, lejana del abrazo paterno. Tono y tema similares manifiesta otro poema, sin título, en el que la palabra clave -y como se ha advertido anteriormentees, precisamente, «olvido». Pero en esta ocasión, al interlocutor desconocido -tal vez una mujer-Gaya le pide precisamente una huida de la memoria, hacia el olvido, como manera de cancelar, al menos provisionalmente, el sufrimiento. Muy cercana a la primera nana es «Nana para un Lázaro», que deja al lector de Gaya un tanto desconcertado. ¿El poeta habla a sí mismo cuando invoca «iLevántate y anda, / ajusta el sufrir!»? ¿O es que él, al advertir el abismo de zozobra sobre el que se mueve, escribe estos versos para protegerse y estas palabras tendrían, entonces, una función apotropaica? Nadie sino el poeta conocía el secreto de estos poemas, pero la lectura que acabamos de dar no parece lejana de la verdad. Los últimos dos poemas, «Pequeña piedra de adhesión» y «Canción extraña», están inspirados por

\footnotetext{
Sobre este poema no podemos obviar la existencia de un lienzo de 1955 que Gaya titula La lámpara (mi cama reflejada en el espejo), y sí evidenciar de nuevo la relación entre la pintura y la escritura en nuestro autor.
} 
aquella soledad que asedió a Gaya de especial manera durante el destierro mexicano (Durante, 2015). En el primero el autor invoca la comprensión de los pocos amigos que seguía teniendo e intenta explicar su aparente lejanía y justificarla en el cierre final del verso: «a vosotros me ata una distancia de hermano». «Canción extraña» se perfila como un diálogo del autor consigo mismo. Gaya se pregunta sobre lo que sabe que no podrá poseer: la mujer, la patria, la hija.

«Canción del sí vivir / y estar desierto», dice el poeta, para volver a decir «Canción del no querer/ y estar sediento. / Canción del sí vendrás, / del no te tengo». «No estar cierto», «estar temiendo», «estar desierto», «estar sediento», para terminar con la parte central del poema «no te tengo» son movimientos de ida y vuelta en que, como en un columpio emotivo, el poeta se impulsa hacia delante, hacia la esperanza del porvenir, pero es condenado a volver sobre su pasado: no tener lo que desea y quedarse en el vacío.

El mismo tema de la experiencia del sufrir, pero con mayor elaboración, es lo que se encuentra en la lectura de los «Ocho poemas imprecisos», fechados en México, 1943-1948. Esos reúnen «Un ademán, el aire», «Asistimos, estamos», «Aquí está, con nosotros», «Tarde», «Y llueve, llueve apenas», «La casa de Dios», «Vuelto hacia sí» dedicado al amigo Cristóbal Hall, y «Epitalamio». En este último poema vuelve a la composición clásica para homenajear al joven amigo poeta Tomás Segovia y su esposa. De estos poemas se desprende cómo el sufrimiento de Gaya parece haber alcanzado una fase dominada por la fuerte desilusión del autor hacia la vida: «La memoria es entonces unos signos borrosos», "Y el amor es un friso de ceniza» son versos que escribe para subrayar la caducidad de lo vivente. $Y$ hasta los sentimientos más sagrados se tiñen de colores falsos cuando declara «La amistad, esa orilla tan estéril, un muro decorado con luces/de egoísmo». No hay manera de salvarse de la disilusión que se proyecta sobre el hombre, como se lee en el poema «Vuelto hacia sí»: «Comprendemos entonces / que la dicha y la pena / sólo son realidades, / una misma materia. Conocer una cosa / es igual que alejarnos, / es perderla del todo, / destruirla en las manos». Tampoco en la composición dedicada a la boda de Segovia el tono se hace liviano. La escena de la boda es mirada por Gaya desde lejos, como algo ya conocido que vuelve a repetirse en la historia: «Desde aquí, desde el centro / de esta cárcel abierta». Sin embargo, las palabras más amargas son las de Gaya en «La casa de Dios», en que el pintor intenta un diálogo con Dios ${ }^{8}$. En otro poema de

\footnotetext{
${ }^{8}$ No es la primera vez que nuestro autor emprende un diálogo con lo divino. Ya en 1939, en el poema «A Dios», él había alzado el rostro al cielo para pedirle una explicación de todo lo que le había quitado: la casa, la familia, la patria. «Me despojas de todo, permitiendo / que yo mismo contemple esas cenizas»: ya en el íncipit, Gaya interroga a la divinidad sobre el porqué de tanta saña hasta quitarle la posibilidad de morir: «Me arrancaste mi llanto, y ya no lloro; / me arrancaste mi vida, y ya no vivo; / si el morir me arrebatas, ¿qué me dejas?».
} 
los ochos, «Asistimos, estamos», el tema del divino lejano como un dios griego se repite. De las cosas buenas del pasado -la niñez, la plaza del pueblo, la madre tan querida- solo queda una imagen, un recuerdo ya que, como escribe Gaya, «Todo es de Él». No hay posibilidad de amor porque todo llega a ser una sombra, una mentira, como concluye al final de la composición. El coloquio con Dios lo conduce a buscarlo en su casa para descubrir solo «relieves y huecos». La casa está vacía: aquel Dios «se esconde, nos huye»?.

Del mismo periodo son los poemas publicados en la revista porteña De mar a mar bajo el lema «Poemas de un diario»: «Tiempo», «Tarde [I]», «Tarde [II]», «Tarde $[\mathrm{III}] »$, «Al destino», junto a «El aire» publicado en México en $1944^{10}$. En todos ellos se reconoce en la reiteración de las que ya hemos definido palabras clave, no solo de la poética gayesca sino de su escritura. Pero lo que sobresale en estos poemas es una mayor elaboración del dolor, lo que en el autor podemos definir como la sublimación de sus dolencias en verso. Esta idea resulta vigente, de especial manera, en los poemas dedicados a la tarde, donde un momento del día devuelve al autor emociones que evocan lo perdido. La misma ilusión que vimos en otros poemas se revela en «El aire», pero aquí es la naturaleza la que a través del aire engaña al poeta, llevándole hacia recuerdos e ilusiones de su pasado feliz, aunque todo es «un engaño / recubierto de formas, / disfrazado de vida». La reiteración de la idea de mentira, de ilusión que el ser humano padece, es sin duda una de las claves para interpretar la poesía de Ramón Gaya en estos años. Pero más allá de lo que acabamos de comentar, en los poemas de la década de los 40, emergen otros términos relevantes. «Agua» es indudablemente una de estas palabras, y no solo porque el pintor construye su pensamiento ensayístico sobre la idea de pintura como arte acuoso, sino porque el líquido elemento se encuentra en los versos. «La memoria es entonces [...] una losa de agua» escribe en el poema «Un ademán, el aire» (México 1943-1948). Y en el mismo lugar, quizás por primera vez, Gaya se refiere a la pintura al escribir «Y quisimos ser dueños / de esa agua, esa agua / verdadera que copia / la mentira que somos». Además, recordamos la referencia a «un agua escondida» ${ }^{11}$ que en otro poema de estos años evoca los pasos en prosa del propio autor sobre el arte pictórico.

Es la misma agua del pozo citada en el poema «Tiziano», que pertenece a los poemas del cuarto apartado que tratan sobre el tema de la pintura y que incluye «El

\footnotetext{
${ }^{9}$ Sobre el coloquio que Gaya entabla con el Creador, véanse Durante (2015: 105-116); García Montalvo (2011); Moreno (1980: 87-92).

${ }^{10}$ Este poema fue publicado en El hijo pródigo (IV, n. ${ }^{\circ} 41,15$ de agosto de 1946, págs.79-81) bajo el título «Diarios de un pintor» que, junto a dicha composición, se incluía también «Asistimos, estamos» y «Aquí está, con nosotros».

${ }^{11}$ «Y llueve, llueve apenas».
} 
Tevere a su paso por Roma» de $1974^{12}$. Ya en «Tiempo» de 1943, Gaya se había referido al día y cómo este se iba «en su agua», mientras en la composición de 1944 «Figurilla» se hacía referencia a «un pozo de antes, / agua fija y doliente». Sin embargo, en los poemas del último periodo, el agua resulta aún más presente en la escritura y en la pintura de Gaya. De la misma manera, palabras clave son el término «corteza» y el giro que Gaya usa a menudo de «más acá», relacionadas con el tema de la corporeidad y sus limitaciones, que veremos más adelante.

El cuarto grupo de poemas, sobre el que nos detenemos, es aquel que reúne quellas composiciones escritas desde los años setenta hasta la muerte de Ramón Gaya, cuyo eje principal es representado por el tema de la pintura y, de manera general, del arte. Estos se caracterizan por el tono apaciguado y sereno que los diferencia respecto a la producción poética de la década de los 30 y los 40 . La distancia espacio-temporal - están ya escritos en Europa, concretamente en Italia y, más tarde, en España- ha mudado la voz del autor que usa el verso para describir emociones sin dialogar con su soledad. Los poemas, ya maduros, trasmiten un equilibrio interior, una serenidad que acompañará al pintor y a su obra pictórica, ensayística y poética hasta el final de su vida. A este periodo partenecen los poemas: «Tiziano» -compuesto en Venecia en el año 1976-, «Velázquez (Soneto con estrambote en prosa)», «Del pintar»-que incluye «Trazado de desnudo», «Mansedumbre de obra», «Mano vacante»- y «De pintor a pintor». A estos añadimos, por homogeneidad cronológica y temática, «El Tevere a su paso por Roma», «Para el Crepúsculo de Michelangelo» (Florencia, 1980), «Dos divertimenti» y «Para el Crepúsculo». «Tiziano» está dedicado a uno de los pintores más estimados por Gaya y es, junto con «Velázquez (soneto con estrambote en prosa)», lo que podemos definir como un homenaje ${ }^{13}$ en versos que Ramón Gaya dedica a sus maestros. Ambos poemas perfilan el carácter del arte de los dos pintores. De Tiziano Gaya aprecia que su pincel toque «los enigmas que escucha» y «el silencio de música». Las obras evocadas -El entierro de Cristo y, probablemente, la Danae- se revelan «más allá o más acá [nótese la expresión] / de la simple pintura». La realidad viva de lo retratado por Tiziano es destacada por el autor, que en ella reconoce aquella en que «el hombre se alegra de volver a su cuna». Bajo la mirada de Gaya, la pintura del italiano es artífice de la reconducción del ser humano a su verdadera naturaleza. El poema «Velázquez», en cambio, inicia con lo que sobresale en el pintor: «el borrar». «Mucho ha sido borrado por su mano», le dice Gaya a su maestro más querido en el primer verso. Y en ese borrar, ese quitar en lugar de añadir -colores- reside la especificidad de Velázquez, a quien Gaya toma como inspiración tanto en el pensamiento como en el verso poético. La

\footnotetext{
${ }^{12}$ Fue pintado, por cierto, en el excelente reflejo de Castel Sant'Angelo en Roma.

13 Veánse Muñoz (2012) y Leyra (2017). Además, hay que recordar el estudio de Miriam Moreno Aguirre, Otra modernidad. Estudios sobre la obra de Ramón Gaya (2018).
} 
realidad, inclusive aquella del objeto pintado, se alcanza quitando y no añadiendo colores. Llegar a la realidad significa, entonces, llegar a alcanzar lo sagrado, tal y como lo explica en el strambote que acompaña los versos. Allí aparece el blanco del verdadero creador, al parecer de Gaya: llegar al alma de la realidad sin desnudarla ni taparla. Por este motivo, en «Mansedumbre de obra» el autor dicta: «Pintar no es acertar a la ligera, / ni es tapar, sofocar, dejar cegado / ese abismo que ha sido encomendado / a la sed y al silencio de la espera». Y la espera es la del pintor que se vuelca en la obra esperando, sin sofocar a la criatura que está bajo su pincel. Estas son ya prescripciones del Gaya maduro, que desarrolla en versos el nucleo de su idea de la actividad pictórica. Así, en «Trazado de desnudo», evoca una obra maestra de Miquel Ángel que lo impactó, I prigioni, en donde «la caja del hombre, es su corteza ${ }^{14}$ / solitaria, sin él; todo es regazo, / lugar, concavidad, sedienta calma». Entonces, a este regazo, a esta concavidad -otra palabra reiterada- acude el alma, como escribe Gaya en el verso que cierra la composición. En esta actividad serena, casi determinada por la espera, el autor retrata la «Mano vacante» del pintor, su mano, que declara «ni sabia, ni brutal, ni pensativa, / ni artesana, ni loca, ni ambiciosa, / ni puede ser sutil ni artificiosa; / la mano del pintor -la decisiva-». Es mano, como escribe más adelante, «de testigo [...] mano desnuda, de mendigo», la mano del creador a la espera delante al lienzo. En otra composición Gaya pone en versos otra idea principal de su pensamiento, «De pintor a pintor». El epígrafe de Tiziano «El atardecer es la hora de la pintura» es el broche con el que Gaya sintetiza su sentimiento hacia la pintura, pero es especialmente interesante evidenciar lo que la pintura, según nuestro autor, no es. «Pintar no es ordenar, ir disponiendo [...] colocar unas sombras sobre un plano, /empeñarte en tapar, en ir cubriendo». Se repite el tema del añadir, de poner colores en contraposición del quitar, desnudar. «Pintura no es hacer»: ya hemos adelantado la pasividad del pintar, en su sereno esperar.

Entonces ¿qué significa pintar para Gaya? La explicación, sintética y poética, la desarrolla en los siguientes versos: «pintar es tantear-atardeciendo- / la orilla de un abismo con tu mano, / temeroso adentrarte en lo lejano, / temerario tocar lo que vas viendo. / Pintar es asomarte a un precipicio, / entrar en una cueva, hablarle a un pozo/ y que el agua responda desde abajo». La actividad pictórica se perfila, por tanto, como una actividad aventurada, que requiere valor ya que pide rozar lo abismal. El pozo, el abismo, el precipicio, la cueva son lugares oscuros a los que se accede sin conocer lo que nos espera. El pintor permanece delante del lienzo, esperando lo que aún desconoce, sin saber lo que saldrá de sí mismo. Por consiguiente Gaya nos describe un diálogo con la parte oscura que reside en los seres humanos. Y estos mismos lugares, retratados en sus versos - pozo, abismo, cueva-, son, además, los

\footnotetext{
${ }^{14}$ Fíjese el lector en la recurrencia del término para indicar la corporeidad.
} 
mismos que, como sucede con la concavidad que Gaya describe en otros lugares, reciben y acogen aquella agua escondida. Este soneto es, pues, una declaración de intenciones en contra del pintor artista encantado de su narcisismo. «Pintura [...], es sacrificio», es, en síntesis, el lema de la meditación de Gaya sobre el arte pictórico. Nuestro autor ha ido deshojando las capas sobrestructurales del arte de la pintura hasta llegar a su alma, así como dicta en el final del soneto «De pintor a pintor». Esta es la tarea que Gaya reconoce en el Miguel Ángel ${ }^{15}$ de I Prigioni, unas esculturas tan evocadoras y caracterizadas por esa concavidad anteriormente citada. El que se dirige hacia la noche, el Crepúsculo, parece perfilado sin estar acabado, y reproduce aquella concavidad que Gaya reconoce en las palabras «Queda un $\mathrm{Algo}^{16}$, es un algo verdadero / que no cede ni actúa: embellecido ${ }^{17}$ ).

\section{Bibliografía}

Agamben, Giorgio, «Il luogo della poesia. Lettura di un sonetto di Ramón Gaya», en VV. AA., Homenaje a Ramón Gaya, Murcia, Editorial Regional de Murcia, 1980, págs. 31-35.

Andújar, Manuel, «La dispar y absoluta singularidad de Ramón Gaya», en VV.AA., Homenaje a Ramón Gaya, Murcia, Editorial Regional de Murcia, 1980, págs. 43-47.

Dennis, Nigel (ed.), Ramón Gaya de viva voz. Entrevistas (1977-1998), Valencia, Pre-Textos, 2008.

De Rivas, Enrique, «La mano de Gaya (razia personal en un huerto murciano)», en VV.AA., Homenaje a Ramón Gaya, Murcia, Editorial Regional de Murcia, 1980, págs. 97-101.

De Rivas, Enrique, «La poesía de Ramón Gaya», en Rosa Corral, Arturo Souto Alabarce y James Valender (eds.), Poesía y exilio: los poetas del exilio español en México, México, El Colegio de México, 1995, págs. 337-342.

Durante, Laura Mariateresa, La letteratura come esperienza filosofica nel pensiero di María Zambrano. Il periodo romano (1953-1964), Roma, Aracne, 2008.

Durante, Laura Mariateresa, Ramón Gaya. El exilio de un creador, Roma, Edizioni Nuova Cultura, 2013.

\footnotetext{
${ }^{15}$ Recuérdese que Gaya dedica al Crepúsculo de Miguel Ángel en Florencia dos composiciones.

${ }^{16}$ En el poema «Para el Crepúsculo» Gaya subraya otra vez la palabra «algo», ya desde el íncipit: «Es un Algo que vive» y termina «Es un algo que es libre/ sin salir de aquí dentro». Y este «Algo» es puesto en luz por Enrique de Rivas en «La mano de Gaya (razia personal en un huerto murciano)» (1980: 97-101).

${ }^{17}$ Fíjese el lector en el retorno al término «embeleso», que ya anotó Manuel Andújar en «La dispar y absoluta singularidad de Ramón Gaya» (1980).
} 
Durante, Laura Mariateresa, «El exilio de Ramón Gaya en México», en Adalberto Santana y Aurelio Velázquez (eds.), Docencia y cultura en el exilio republicano español, México, Universidad Nacional Autónoma de México, 2015, págs. 155166.

García Montalvo, Pedro, «Un cielo gris de octubre (Gaya creyente)», Escritura e imagen, n. ${ }^{\circ} 7$ (2011), págs. 247-251.

Gaya, Ramón, Obra completa, ed. de Nigel Dennis e Isabel Verdejo, Valencia, PreTextos, 2010.

Leyra Soriano, Ana María, "A partir de Cuando las imágenes toman posición. Un ejemplo en la cultura de habla hispana: Ramón Gaya y sus "homenajes"», Anthropos, n. ${ }^{\circ}$ 246, 2017, págs. 64-77.

Moreno Aguirre, Miriam, Otra modernidad. Estudios sobre la obra de Ramón Gaya, Valencia, Pre-textos, 2018.

Muñoz, Jacobo, «Pintura y pensamiento en Ramón Gaya», Escritura e imagen, n. ${ }^{\circ} 7$ (2011), págs.183-188.

Muñoz Millanes, José, Los Homenajes de Ramón Gaya, Valencia, Pre-Textos, 2012.

Pascual Gay, Juan, «Ramón Gaya: "junto a un pasado sólo huellas”», en Manuel Aznar Soler (ed.), Las literaturas del exilio republicano de 1939, Bellaterra, Gexel, vol. I, 2003, págs. 561-568.

Paz, Octavio, «Realismo y poesía», en Catálogo Ramón Gaya en México 19391956, Murcia, 1996.

Pérez Sánchez, Alfonso E., Ramón Gaya. La pintura como sacrificio, Murcia, Museo Ramón Gaya, 2002.

Segovia, Tomás, «Ramón Gaya, poeta», en Rosa Corral, Arturo Souto Alabarce y James Valender (eds.), Poesía y exilio: los poetas del exilio español en México, México, El Colegio de México, 1995, págs. 346-347.

Trapiello, Andrés, «Ramón Gaya y su poesía», en VV. AA., En torno a Ramón Gaya, Murcia, Museo Ramón Gaya, 1991, págs. 67-89. 